\title{
ANALISIS PENGARUH HARGA TERHADAP KEPUTUSAN PEMBELIAN DI ONLINE SHOP TOKOPEDIA
}

\author{
Refika Rahmadani, Febryandhie Ananda \\ Sekolah Tinggi Ilmu Ekonomi KBP \\ Email: refikar4@gmail.com \\ febryandhie@akbpstie.ac.id
}

\begin{abstract}
Consumer purchasing decisions are an important factor for determining the existence of a company. purchasing decisions (Kotler \& Philip, 2009) are actions of buyers / consumers to want to buy or not a product. This study aims to find out and provide an overview of how prices affect purchasing decisions in the tokopedia online shop. Data collection techniques in this study use the type of interval data and primary data sources by distributing questionnaires. Data analysis techniques used descriptive statistics, classical assumption tests and hypothesis testing using simple linear regression methods. The results of the purchase decision at the tokopedia online shop.
\end{abstract}

Keywords: purchase decision, price influence, online shop

\section{PENDAHULUAN}

Keputusan pembelian konsumen menjadi faktor yang penting untuk penentu eksistensi suatu perusahaan. Suatu perusahaan dapat terus dikatakan eksis jika konsumen yang memutuskan melakukan pembelian produk dari suatu perusahaan mendapat respon positif dari konsumen tersebut. Menurut (Kotler \& Philip, 2009) keputusan pembelian merupakan tindakan dari pembeli/konsumen untuk mau membeli atau tidak suatu produk. Biasanya konsumen mempertimbangkan harga, kualitas dan produk sudah yang sudah dikenal oleh masyarakat luas. Peneliti menggunakan variable keutusan pembelian ini karena studi tentang keputusan pembelian masih layak untuk diteliti mengingat semakin banyaknya produk yang beredar mengakibatkan pentingnya berbagai pertimbangan untuk masyarakat untuk melakukan keputusan pembelian. Dalam kasus di sini keputusan pembelian yang dilakukan oleh konsumen tokopedia adalah keputusan pembelian di tokopedia, tentunya para konsumen telah banyak melakukan transaksi pembelian yang berulang. Pembelian dipengaruhi oleh beberapa faktor seperti iklan, citra merek produk, harga yang ditawarkan dan lain sebagainya. 
Dalam melakukan keputusan pembelian biasanya hal pertama yang dipertimbangan konsumen dalam memilih produk adalah dengan melihat harga atas produk tersebut (Ananda, Putra, \& Hendrastyo, 2017; Ananda \& Zulvia, 2018). Inilah mengapa peneliti menggunakan harga sebagai salah satu variable dalam benelitian ini. Harga memiliki peran yang sangat penting dalam pengambilan keputusan. Tinggi rendahnya harga suatu produk selalu menjadi perhatian utama para konsumen saat mereka mencari produk yang mereka butuhkan, sehingga harga yang ditawarkan kepada konsumen menjadi pertimbangan khusus, sebelum mereka memutuskan untuk membeli barang atau menggunakan suatu jasa. Dari kebiasaan para konsumen, stategi penetapan harga sangat berpengaruh penting terhadap penjualan maupun pemasaran untuk suatu produk yang ditawarkan.

Maka sudah selayaknya dimanfaatkan oleh masyarakat khususnya nupara pengusaha untuk memasarkan produk atau jasanya melalui internet atau yang biasa disebut dengan online shop.Banyaknya web-web serta portal web transaksi online memudahkan para pembeli untuk belanja tanpa ribet tapi dengan banyaknya situs online shop maka persaingan harga sangat mungkin terjadi.

Tokopedia memiliki misi mulia yaitu ingin penjadi perusahaan teknologi di Indonesia untuk pemerataan ekonomi secara digital. Platform marketplace terdepan di Indonesia, Tokopedia, memberdayakan jutaan merchant dan konsumen untuk berpartisipasi dalam masa depan perekonomian. Visi Tokopedia adalah membangun sebuah jaringan dimana siapa pun bisa memulai dan menemukan apa pun. Layanan Tokopedia telah memungkinkan jutaan individu, UMKM dan pemilik bisnis di Indonesia menjual produk kepada pelanggan di seluruh Indonesia. Para merchant Tokopedia telah membuka puluhan juta lapangan pekerjaan baru di Indonesia. Tokopedia yang berdiri sejak tanggal 17 Agustus 2009 dan memiliki komitmen untuk mengembangkan bakat dari masyarakat untuk mewujudkan beragam ide dan inovasi dalam rangka mencapai misi peningkatan dan pemerataan ekonomi secara digital di Indonesia. Demi mewujudkan misi besar tersebut, Tokopedia membutuhkan talentatalenta terbaik dari masyarakat indonesia yang memiliki semangat yang sama untuk membantu perekonomian Indonesia, siapa pun dimana pun, bisa mewujudkan mimpi dan cita-cita mereka (Tokopedia, 2018) .Menurut penelitian dari (Kurniasari, 2013) Hasil penelitian menunjukkan bahwa harga, kualitas produk dan kualitas pelayanan memiliki pengaruh yang positif dan signifikan terhadap keputusan pembelian. (Arwiedya \& Ridzky, 2011) harga termasuk salah satu faktor yang berhubungan positif dan signifikan terhadap keputusan pembelian via internet pengaruh harga sangat mempengaruhi terhadap keputusan pembeli . Di penelitian yang dilakukan oleh (Akbar, 2012) menunjukan terdapat hubungan yang signifikan antara variable independen citra merek, harga, dan kualitas produk terhadap variabel dependen yaitu keputusan pembelian. Sedangkan di penelitian (Nurjanah, 2013) mengungkapkan bahwa variabel persepsi harga berpengaruh positif dan signifikan terhadap keputusan pembelian konsumen. 
Atas dasar penelitian terdahulu dapat dibuat hipotesis bahwa harga berpengaruh terhadap keputusan pembelian online

Ha : Harga berpengaruh terhadap keputusan pembelian di toko Online

Ho : Harga tidak berpengaruh terhadap keputusan pembelian di toko Online

\section{METODE PENELITIAN}

Metode yang digunakan dalam penelitian ini adalah metode kuantatif, . Penelitian kuantitatif yaitu jenis penelitian dimana proses pengkajian informasi dihasilkan berbentuk angka-angka dan melakukan analisis data dengan prosedur statistik (Afsari, 2015) dengan menggunakan pendekatan korelasional. Penelitian kuantitatif disebut juga sebagai metode positivistik karena berlandaskan pada filsafat positivisme. Dalam penelitian ini terdapat 1 variable independen dan 1 variable dependen, variable independen dalam penelitian ini adalah pengaruh harga sedangkan variable dependen dalam penelitian ini adalah keputusan pembelian

Jenis data yang digunaan dalam penelitian ini adalah data interval yaitu hasil pengukuran yang dapat diurutkan atas dasar criteria tertentu serta menunjukan semua sifat yang dimiliki oleh data ordinal. Kelebihan sifat data interval dibandingkan dengan data ordinal adalah memiliki sifat data interval memiliki sifat kesamaan jarak (equity interval) atau memiliki rentang yang sama antara data yang diurutkan.

Sumber data yang digunakan dalam penelitian ini adalah data primer, data primer merupakan jenis data penelitian yang berupa opini, sikap, pengalaman atau karakteristik dari seseorang atau sekelompok orang yang menjadi subjek penelitian atau responden.

Untuk kegiatan penelitian ini data skor di dapat melalui kuesioner yaitu sebagai data interval setelah alternatif jawabannya diberikan skor yang ekuivalen atau setara dengan skala interval. Skala Likert digunakan untuk mengukur sikap, pendapat dan persepsi seseorang atau sekelompok orang tentang fenomena sosial. Dengan skala Likert ini variabel yang akan diukur dijabarkan menjadi indikator variabel. Setelah itu dijadikan sebagai titik tolak untuk menyusun item-item instrumen yang dapat berupa pernyataan atau pertanyaan (Sugiyono, 2016), misalnya:

a. Skor (5) untuk jawaban "Sangat Setuju"

b. Skor (4) untuk jawaban "Setuju"

c. Skor (3) untuk jawaban "Netral"

d. Skor (2) untuk jawaban "Tidak Setuju"

e. Skor (1) untuk jawaban "Sangat Tidak Setuju"

Penilaian tersebut dapat dilihat dalam tabel berikut ini: 
Tabel 1

Pengukuran Skala Likert

\begin{tabular}{|l|l|l|}
\hline No & Kategori Jawaban & Bobot Nilai \\
\hline 1 & Sangat Setuju (SS) & 5 \\
\hline 2 & Setuju (S) & 4 \\
\hline 3 & Netral & 3 \\
\hline 4 & Tidak Setuju (TS) & 2 \\
\hline 5 & Sangat Tidak Setuju (STS) & 1 \\
\hline
\end{tabular}

Sumber data yang dipakai dalam penelitian ini adalah data primer. Dimana data primer merupakan jenis data penelitian yang berbentuk opini, sikap, pengalaman atau karakteristik dari seseorang atau sekelompok orang yang menjadi subyek dalam penelitian ini atau responden (Afsari, 2015).

Data primer ini berasal dari sumber asli atau pertama, data ini tidak tersedia dalam bentuk terkompilasi ataupun dalam bentuk file, data ini harus dicari melalui narasumber atau dalam istilah teknisnya responden, yaitu orang yang kita jadikan objek penelitian atau orang yang kita jadikan sebagai sarana mendapatkan informasi ataupun data (Sarwono, 2006).

Tanggapan yang disampaikan oleh responden berupa respon tertulis melalui kuesioner yang telah diajukan oleh peneliti. Kuesioner yaitu daftar-daftar pernyataan yang memiliki hubungan dengan variabel yang akan diteliti yaitu karakteristik laporan keuangan, serta kriteria-kriteria yang berhubungan dengan akuntabilitas kinerja karayawan.

Dalam penelitian ini, metode data yang digunakan meliputi :

A. kuesioner merupakan salah satu metode pengumpulan data yang dilakukan dengan memberikan daftar pertanyaan kepada responden, baik pernyataan yang sifatnya tertutup maupun terbuka. Pertanyaan bersifat tertutup, diukut menggunakan skala internal 1-5 yaitu sangat setuju, setuju, netral/ rata-rata, tidak setuju, dan sangat tidak setuju.

B. Kuesioner online

Selain menggunakan kuesioner biasa penelitian ini juga menggunakan kuesioner online untuk mengumpulkan data, metode ini menggunakan fasilitas google form untuk menyebarkan kesioner.

Uji Validitas digunakan untuk mengukur valid tidaknya suatu kuesioner. Suatu kuesioner dapat dikatakan valid apabila pertanyaan yang terdapat dalam kuesioner mampu menggunggkapkan suatu yang akan diutur oleh keusioner tersebut. Kuisoner dikatakan valid jika pertanyaan pada kuisoner mampu untuk mengungkapkan sesuatu yang akan diukur oleh kuisoner tersebut (Ghozali, 2009). Uji validitas dalam penelitian ini yaitu dengan melakukan KMO dan Barlett's Test. Nilai Kaiser-mayer-olkin test berkisar dari $0-1$, semakin mendekati 1 , berarti semakin bagus. Nilai yang dapat 
diterima adalah diatas 0,6. Nilai Barlett's yang dapat diterima adalah jika signifikansi dibawah 0,06 dan yang paling bagus jika dibawah 0,01(Piyatno, 2014)

Uji reliabilitas digunakan untuk mengukur suatu kuesioner yang merupakan indikator dari variabel. Suatu kuesioner dapat dikatakan reliabel atau handal apabila jawaban seseorang terhadapa pernyataan adalah stabil atau konsisten dari waktu ke waktu. Suatu variabel dikakan handal apabila nilai croanbach alpha $(\alpha)$ lebih besar dari 0,6. Namun apabila nilai croanbach alpa lebih kecil dari 0,6 maka kuesioner dianggap kurang handal sehingga apabila dilakukan penelitian ulang terhadap variabel-variabel tersebut pada waktu dan dimensi yang berbeda, kesimpulan akan berbeda (Ghozali, 2009)

Pengujian ini bertujuan untuk mengetahui apakah dalam sebuah model regresi, eror yang dihasilkan mempunyai retrebusi atau tidak. Model regresi yang baik adalah model regresi yang memiliki distribusi data normal atau yang mendekati normal(Ghozali, 2009). Pengujian dialkukan dengan menggunakan pengujian Kolmogorov Smirnov. Pengujian dengan ini akan menunjukan bahwa data terdistribusi normal ketika nilai sig > 0,05 dan sebaliknya ketika nilai sig > 0,05 maka dapat disimpulkan bahwa data tidak terdistriusi normal.

Uji Homogenitas digunakan untuk mengeahui varian dari beberapa populasi sama atau tidak. Uji ini biasanya dilakukan sebagai prasyarat dalam analisis independent sampil T Test dan Anova. Asumsi yang mendasari dalam analisi of varians (ANOVA) adalah bahwa varian dai beberapa populasi adalah sama.

Analisis regresi digunakan untuk mengetahui seberapa besar pegaruh variabel bebas yaitu: harga (X) yang berpengaruh terhadap keputusan pembelian konsumen (Y) pada online shop tokopedia, . Adapun bentuk persamaan regresi linier yang digunakan dalam penelitian ini sebagai berikut:

$$
\mathrm{KP}=\mathrm{bH}+\mathrm{e}
$$

Keterangan:

$$
\begin{array}{ll}
\mathrm{KP} & =\text { Keputusan pembelian konsumen } \\
\mathrm{B} & =\text { Koefisien regresi } \\
\mathrm{H} & =\text { Harga } \\
\mathrm{e} & =\text { Kesalahan penggunaan }
\end{array}
$$

Ketepatan fungsi regresi sampel dalam menaksir nilai aktual dapat diukur dari Goodness of fit nya (Ghozali, 2009). Secara statistik, dapat diukur dari nilai statistik f, nilai koefisien determinasi dan nilai statistik t. Menurut (Ghozali, 2009). Perhitungan statistik disebut signifikan secara statistik apabila nilai uji statistiknya berada dalam daerah kritis (daerah dimana H0 ditolak). Sebaliknya disebut tidak signifikan bila nilai uji statistiknya berada dalam daerah dima

Uji statistik ini pada dasarnya menunjukkan seberapa jauh pengaruh satu variabel independen secara individual menerangkan variasi variabel dependen. Hipotesis yang digunakan adalah : 
Ho : bi $=0$, berarti variabel independen (harga, jenis media promosi, resiko kinerja dan keragaman produk) tidak berpengaruh signifikan terhadap variabel dependen (keputusan pembelian).

$\mathrm{Ha}: \mathrm{bi} \neq 0$, berarti variabel independen (harga, jenis media promosi, resiko kinerja dan keragaman produk) memiliki pengaruh yang signifikan terhadap variabel dependen (keputusan pembelian).

\subsection{Definisi Operasional Variabel}

\begin{tabular}{|c|c|c|c|c|}
\hline NO & Variabel & DefinisiVariabel & Indikator & Pernyataan \\
\hline 1. & Harga (X) & $\begin{array}{lr}\text { Harga adalah } \\
\text { sejumlah uang } \\
\text { yang dibebankan } \\
\text { atas suatu } \\
\text { produk, atau } \\
\text { jumlah dari nilai } \\
\text { yang ditukar } \\
\text { konsumen atas } \\
\text { manfaat-manfaat } \\
\text { karena memiliki } \\
\text { atau } \\
\text { menggunakan } \\
\text { produk tersebut } \\
\text { (Kloter } \\
\text { Armstrong, \& } \\
\text { 2001) }\end{array}$ & $\begin{array}{l}\text { 1. Konsumen } \\
\text { menggunaka } \\
\mathrm{n} \text { harga } \\
\text { sebagai } \\
\text { indikator } \\
\text { kualitas } \\
\text { 2. Adanya } \\
\text { informasi } \\
\text { mengenai } \\
\text { harga } \\
\text { 3. Kemampuan } \\
\text { untuk } \\
\text { membeli } \\
\text { 4. Perbandingan } \\
\text { dengan harga } \\
\text { di Online } \\
\text { Shop lainnya }\end{array}$ & $\begin{array}{l}\text { 1. Menurut anda } \\
\text { harga barang di } \\
\text { tokopedia yang } \\
\text { ditunjukan label/ } \\
\text { gambar sesuai } \\
\text { dengan kualitas } \\
\text { barang } \\
\text { 2. Menurut anda } \\
\text { informasi } \\
\text { mengenai harga } \\
\text { produk yang ada } \\
\text { di tokopedia } \\
\text { membantu untuk } \\
\text { membandingkan } \\
\text { produk sejenis. } \\
\text { Menurut anda } \\
\text { dengan paru } \\
\text { mengetahui harga } \\
\text { suatu produk di } \\
\text { tokopedia dapat } \\
\text { mengukur } \\
\text { kemampuan } \\
\text { untuk membeli. } \\
\text { Menurut anda } \\
\text { Harga produk } \\
\text { yang ada di toko } \\
\text { online lebih } \\
\text { murah daripada } \\
\text { harga produk } \\
\text { yang ada di online } \\
\text { shop lainnya }\end{array}$ \\
\hline 2. & $\begin{array}{l}\text { Keputusan } \\
\text { Pembelian } \\
\text { (Y) }\end{array}$ & $\begin{array}{l}\text { Menurut (Kotler } \\
\& \text { Philip, 2009) } \\
\text { keputusan } \\
\text { pembelian }\end{array}$ & $\begin{array}{l}\text { 1. Kemantapan } \\
\text { pada sebuah } \\
\text { produk. }\end{array}$ & $\begin{array}{l}\text { 1. Menurut anda } \\
\text { harga } \\
\text { merupakan } \\
\text { faktor utama }\end{array}$ \\
\hline
\end{tabular}




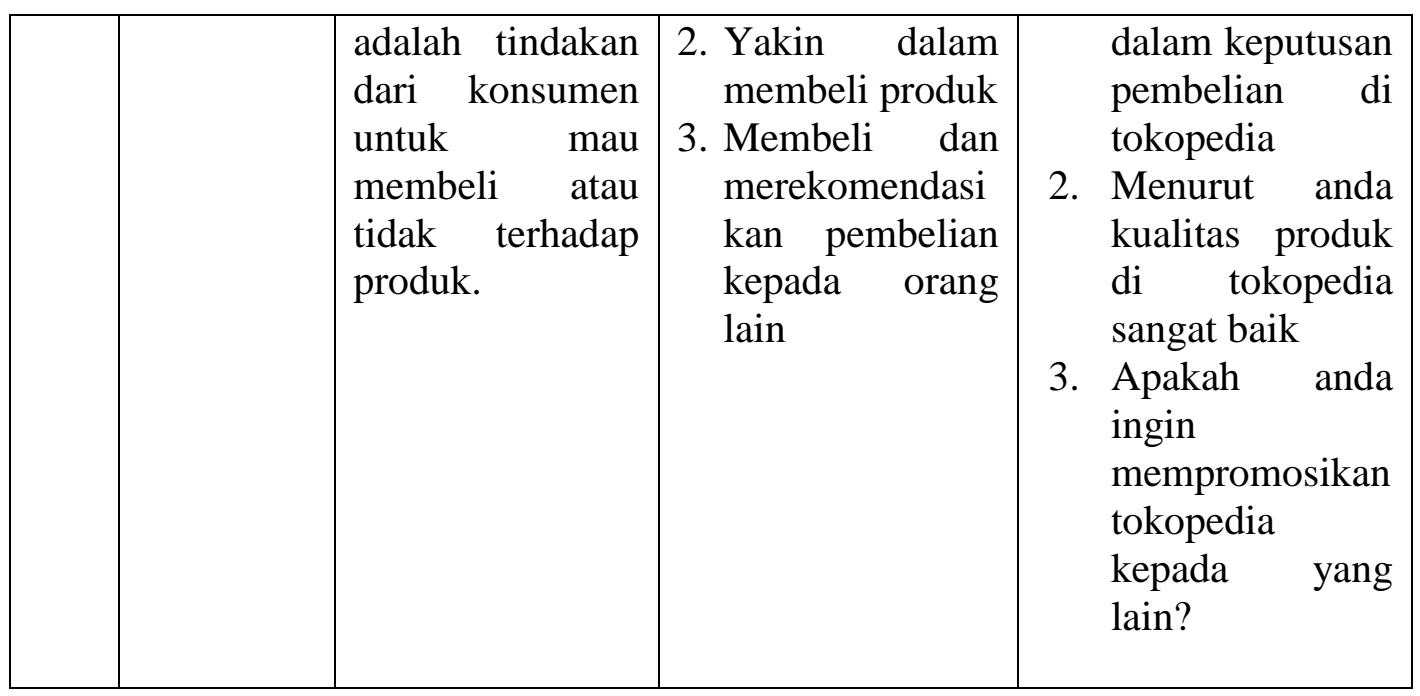

\section{Hasil dan Pembahasan}

Dalam kuesioner penelitian ini terdapat bagian pernyataan-pernyataan dalam bentuk skala likert untuk masing-masing variabel, baik itu variabel independen maupun dependen yang digunakan didalam penelitian ini. Pernyataan-pernyataan itu berhubungan dengan respon pembeli terhadap pengaruh harga di online shop tokopedia beserta keputusan pembeliannya. Dimana dalam kuesioner tersebut terdapat 7 pertanyaan yang terdiri dari 4 pertanyaan yang mewakili variable harga dan 3 pertanyaan yang mewakili variabel keputusan pembelian. Pernyataan ini kiranya dapat mewakili setiap variabel baik variabel independen maupun variabel dependen yang digunakan dalam penelitian ini.

Dalam kuesioner ini responden diminta untuk memberikan penilaian terhadap pandangan mereka mengenai pengaruh harga dan keputusan pembelian dengan menggunakan skala likert dengan nilai 1 sampai dengan 5, dimana 1 = sangat tidak setuju, 2 = tidak setuju, $3=$ netral, $4=$ setuju dan $5=$ sangat setuju.

Tabel 2

Statistik Deskriptif Variabel Penelitian

\begin{tabular}{|l|l|l|l|l|l|l|}
\hline Variabel & Range & $\mathbf{N}$ & $\begin{array}{l}\text { Minim } \\
\text { um }\end{array}$ & $\begin{array}{l}\text { Maxim } \\
\text { um }\end{array}$ & Mean & $\begin{array}{l}\text { Std. } \\
\text { Deviation }\end{array}$ \\
\hline Harga & $1-5$ & 80 & 12.00 & 20.00 & 16.5125 & 2.34922 \\
\hline $\begin{array}{l}\text { Keputusan } \\
\text { Pembelian }\end{array}$ & $1-5$ & 80 & 7.00 & 14.00 & 11.0125 & 1.46256 \\
\hline
\end{tabular}

Dari tabel diatas dapat terlihat statistik deskriptif dari masing-masing variabel. Berdasarkan tabel 4.6, hasil spss 23 menunjukan variabel harga mempunyai nilai minimum sebesar 12.00, nilai maksimum 20.00, nilai mean 16.5125 dan nilai standar deviation sebesar 2.34922. sedangkan untuk variabel pengambilan keputusan 
pembelian menunjukan nilai minimum sebesar 7.00, nilai maksimum 14.00, nilai mean 11.0125 dan nilai standar deviation sebesar 1.46256 .

Dalam pengukuran dan pengujian ini, dilakukan berdasarkan pada data kuesioner yang telah kita dapat setelah penyebaran kuesioner tersebut. Data merupakan gambaran suatu objek atau variabel yang akan diteliti dan juga memegang peranan penting dalam suatu penelitian, sebelum data diolah instrumen ini diuji terlebih dahulu dengan menggunakan uji validitas dan reliabilitas agar memperoleh hasil yang bisa dipertanggung jawabkan.

Uji validitas dilakukan untuk mengetahui seberapa baik suatu instrument dapat mengukur suatu konsep yang seharusnya diukur dan mengetahui pernyataanpernyataan dalam suatu instument adalah valid. Uji ini dilakukan dengan menggunakan analisis faktor (factor analysis) yaitu factor loading untuk memastikan masing-masing pernyataan terklarifikasi pada setiap variabel yang ditentukan.

Kuesioner juga dikatakan valid jika pernyataan pada kuesioner mampu untuk mengungkapkan sesuatu yang akan diukur oleh kuesioner tersebut, Ghozali, Uji validitas dalam penelitian ini yaitu dengan melakukan KMO and Bartlett's Test, untuk mengetahui bahwa suatu indikator yang digunakan dapat mengkonfirmasi sebuah konstruk yang dimana nilai Kaiser-mayer-olkin test berkisar dari 0-1, semakin mendekati 1 , berarti semakin bagus. Nilai yang dapat diterima adalah diatas 0,5 . Nilai Bartlett's test yang dapat diterima adalah jika signifikansi dibawah 0,05 dan yang paling bagus jika dibawah 0,01. Hasil uji validitas terhadap kuesioner, pengukur variabel penelitian disajikan dalam tabel 4.7 di bawah ini:

Tabel 3

Hasil Uji Validitas

\begin{tabular}{|l|l|l|l|}
\hline Variabel & $\begin{array}{l}\text { Batasan } \\
\text { Nilai }\end{array}$ & $\begin{array}{l}\text { KMO and } \\
\text { Bartlett's }\end{array}$ & Keputusan \\
\hline Harga $(\mathrm{X})$ & 0,50 & 0,727 & Valid \\
\hline $\begin{array}{l}\text { Keputusan } \\
\text { Pembelian }(Y)\end{array}$ & 0,50 & 0,551 & Valid \\
\hline
\end{tabular}

Sumber: Data Primer diolah dengan SPSS 23 (2018).

Berdasarkan tabel 4.7 tingkat konsistensi dan akurasi menunjukkan cukup baik. Berdasarkan hasil perhitungan yang ditunjukkan pada tabel diatas nilai Kaiser-MeyerOlkin Measure Of Sampling Adequacy (Kaiser's MSA) sebesar 0,727 > 0,50 sehingga dapat disimpulkan bahwa butir-butir pernyataan pada variabel X dinyatakan valid dan pada variabel Y, nilai Kaiser-Meyer-Olkin Measure Of Sampling Adequacy (Kaiser's MSA) sebesar 0,551 > 0,50 dan dapat disimpulkan juga bahwa butir-butir pernyataan pada variabel Y dinyatakan valid.

Reliabilitas bertujuan untuk mengetahui sejauh mana pengukuran yang telah dilakukan dalam penelitian ini dapat dipercaya dan dapat diandalkan. Uji reliabilitas 
ini diukur dengan menggunakan Cronbach Alpha $\left({ }^{\mathrm{a}}\right)$. Dimana hasil yang dihasilkan lebih besar dari 0,60, maka instrumen yang digunakan dapat dikatakan reliabel. Adapun hasil uji reliabilitas dalam penelitian ini dapat dilihat dalam tabel 4.8 di bawah ini:

Tabel 4

Hasil Uji Reliabilitas

\begin{tabular}{|l|l|l|l|}
\hline Variabel & $\begin{array}{l}\text { Batasan } \\
\text { Nilai }\end{array}$ & $\begin{array}{l}\text { Cronbach's } \\
\text { Alpha }\end{array}$ & Keputusan \\
\hline Harga $(\mathrm{X})$ & 0,60 & 0,795 & Reliabel \\
\hline $\begin{array}{l}\text { Keputusan } \\
\text { Pembelian }(\mathrm{Y})\end{array}$ & 0,60 & 0,773 & Reliabel \\
\hline
\end{tabular}

Sumber: Data Primer diolah dengan SPSS 23 (2018)

Berdasarkan pada tabel 4.8 di atas, hasil pengujian menemukan untuk seluruh variabel mempunyai cronbach's Alpha yang cukup besar yaitu berada di atas 0,60, sehingga dapat dikatakan semua konsep pengukuran masing-masing variabel dari kuesioner adalah reliabel sehingga selanjutnya item-item pada masing-masing variabel tersebut dapat digunakan sebagai alat ukur lebih lanjut.

Uji normalitas memiliki tujuan untuk melihat apakah nilai residual terdistribusi normal atau tidak, dilakukan dengan menggunakan Histogram dan One Sample Kolmogorov-Smirnov. Hasil pengujian dengan One Sample Kolmogorov-Smirnov ini dikatakan normal apabila nilai signifikansi $>0,05$. Sedangkan menurut grafik histogram, data dikatakan normal apabila diagram histogram tersebut mengikuti pola garis berbentuk lonceng. Adapun hasil dari Kolmogorov-Smirnov dan Histogram untuk uji normalitas adalah sebagai berikut:

\section{Tabel 5}

Hasil Uji Normalitas

One-Sample Kolmogorov-Smirnov Test

\begin{tabular}{|c|c|c|c|}
\hline Variabel & $\begin{array}{l}\text { Batasan } \\
\text { Nilai }\end{array}$ & $\begin{array}{l}\text { Asymp. Sig } \\
\text { (2-tailed) }\end{array}$ & Keputusan \\
\hline $\begin{array}{llr}\text { Variabel X dan Y } \\
\text { (Harga } & & \text { dan } \\
\text { Keputusan } & & \\
\text { Pembelian) } & & \end{array}$ & 0,05 & 0,091 & $\begin{array}{l}\text { Terdistribusi } \\
\text { Normal }\end{array}$ \\
\hline
\end{tabular}

Hasil uji normalitas dengan menggunakan uji Kolmogorov-Smirnov dilihat dari nilai signifikan dari data yang telah diolah. Berdasarkan tabel diatas, dapat dilihat bahwa besarnya nilai Kolmogorov-Smirnov Test menghasilkan Asympotic Significance lebih besar dari 0,05 yaitu 0,091 >0,05. Berdasarkan hasil uji ini dapat disimpulkan bahwa model regresi telah memenuhi asumsi kenormalan. 
Uji homogenitas bertujuan untuk melihat sama tidaknya variansi-variansi dua buah distribusi atau lebih. Uji homogenitas dilakukan untuk mengetahui apakah data variabel $\mathrm{X}$ dan variabel $\mathrm{Y}$ bersifat homogen, apabila nilai signifikansinya besar dari 0,05. Adapun hasil uji homogenitas dalam penelitian ini dapat dilihat dalam tabel 4.10 di bawah ini:

\section{Tabel 6}

Hasil Uji Homogenitas

\begin{tabular}{|l|l|l|l|}
\hline Variabel & Batasan Nilai & Homogenitas & Keputusan \\
\hline $\begin{array}{l}\text { Variabel X dan } \\
\text { Y }\end{array}$ & 0,05 & 0,182 & $\begin{array}{l}\text { Bersifat } \\
\text { Homogenitas }\end{array}$ \\
\hline
\end{tabular}

Berdasarkan pada tabel 4.10 di atas, hasil pengujian uji homogenitas memperoleh hasil 0,182. Dimana data dikatakan homo apabila nilai signifikannya besar dari 0,05. Hasil untuk data penelitian ini adalah 0,182>0,05 maka dapat dikatakan varian dari dua kelompok sampel data yaitu Harga dan Keputusan Pembelian adalah sama atau bersifat homogenitas, maka hal ini telah memenuhi asumsi dasar.

Berdasarkan data yang telah dikumpulkan, maka dilakukan analisis untuk pernyataan penelitian guna untuk melihat bagaimana pengaruh akuntansi sektor publik terhadap akuntabilitas kinerja karayawan, di dalam penelitian ini menggunakan analisa regresi sederhana. Hasil pengolahan data dengan bantuan program SPSS 23 dapat dilihat rangkuman hasil empiris penelitian sebagai berikut:

Tabel 7

Hasil Analisis Regresi Linier Sederhana

\begin{tabular}{|l|l|}
\hline Variabel & Koefisien Regresi \\
\hline Konstanta & 6,866 \\
\hline Harga $(\mathrm{X})$ & 0,251 \\
\hline
\end{tabular}

Berdasarkan tabel diatas, dapat dilihat bahwa:

$\mathrm{a}=6,866$ (Konstanta)

$\mathrm{b}=0,251$ (Koefisien pada hasil)

Sehingga diperoleh model estimasi persamaan regresi sederhana adalah sebagai berikut:

$$
\begin{gathered}
\mathrm{KP}=\mathrm{a}+\mathrm{bH}+\mathrm{e} \\
\mathrm{HP}=\mathbf{6 , 8 6 6}+\mathbf{0 , 2 5 1 x}+\mathrm{e}
\end{gathered}
$$

Dimana:

$\mathrm{KP} \quad=$ Keputusan Pembelian

$\mathrm{H} \quad=$ Harga

e $\quad=$ Erorr

Uji T digunakan untuk mengetahui apakah variabel independen secara parsial (individu) berpengaruh terhadap variabel dependen. Variabel-variabel independen yakni Harga terhadap variabel dependen yaitu Keputusan Pembelian. Pengujian ini menggunakan tabel coefficients yang akan disajikan dalam tabel 4.13 berikut: 
Tabel 8

Hasil Uji T

\begin{tabular}{|l|l|l|l|l|l|}
\hline \multirow{2}{*}{ Model } & \multicolumn{2}{|l|}{$\begin{array}{l}\text { Unstandardized } \\
\text { Coefficients }\end{array}$} & $\begin{array}{l}\text { Standardize } \\
\text { d } \\
\text { Coefficients }\end{array}$ & T & Sig. \\
\cline { 2 - 6 } & $\mathbf{B}$ & $\begin{array}{l}\text { Std. } \\
\text { Error }\end{array}$ & Beta & & \\
\hline Constant & 6,866 & 1,076 & & 6,383 &, 000 \\
\hline $\begin{array}{l}\text { X } \\
\text { Harga }\end{array}$ &, 251 &, 065 &, 403 & 3,893 &, 000 \\
\hline
\end{tabular}

a. Dependent Variable: Y Keputusan Pembelian

Berdasarkan atas hasil pengujian yang terdapat dalam tabel 4.13 menghasilkan nilat t dan sig untuk variabel independen yang akan digunakan dalam pengambilan keputusan dalam uji $\mathrm{T}$ ini. Uji $\mathrm{T}$ yang dilakukan dalam penelitian ini dengan melihat nilai signifikannya kemudian dibandingkan dengan tingkat signifikan sebesar 0,05. Jika sig lebih besar dari tingkat signifikan maka $\mathrm{H}_{0}$ akan diterima tapi jika nilai signifikan lebih kecil maka $\mathrm{H}_{0}$ ditolak.

Hipotesis yang akan diteliti, dimana peneliti akan menguji apakah variabel harga akan mempengaruhi Keputusan pembelian di online shop tokopedia.

Hipotesis:

Ha : Harga berpengaruh terhadap keputusan pembelian di toko Online

Ho : Harga tidak berpengaruh terhadap keputusan pembelian di toko Online

Dari hasil nilai sig sebesar 0,000 yang berarti lebih kecil dibandingkan dengan tingkat signifikansi sebesar 0,05 yaitu $0,000<0,05$. Maka dapat disimpulkan bahwa $\mathrm{h}_{0}$ ditolak dan $h_{a}$ diterima yang menunjukkan bahwa harga merupakan faktor yang mempengaruhi keputusan pembelian di toko online.

Koefisien determinasi $\left(\mathrm{R}^{2}\right)$ bertujuan untuk mengukur seberapa jauh kemampuan model dalam menerangkan variasi variabel dependen Ghozali. Nilai $\mathrm{R}^{2}$ semakin mendekati 1 maka variabel independen memberikan hampir semua informasi yang dibutuhkan untuk memprediksi variasi variabel dependen. Sebaliknya semakin kecil maka kemampuan variabel independen dalam menjelaskan variasi dependen sangat terbatas. Nilai koefisien determinasi adalah antara 0 dan 1 . Nilai koefisien detreminasi dapat dilihat pada tabel 4.14 dibawah ini: 
Tabel 4.14

Hasil Uji Koefisien Determinasi $\left(\mathbf{R}^{2}\right)$ Model Summaryb

\begin{tabular}{|l|l|l|l|l|}
\hline Model & $\mathbf{R}$ & R Square & $\begin{array}{l}\text { Adjusted R } \\
\text { Square }\end{array}$ & $\begin{array}{l}\text { Std. } \\
\text { Error of } \\
\text { the } \\
\text { Estimate }\end{array}$ \\
\hline 1 &, $403^{\mathrm{a}}$ &, 163 &, 152 & 1,34685 \\
\hline
\end{tabular}

Berdasarkan hasil uji koefisien determinasi diatas, nilai $\mathrm{R}^{2}$ (Adjusted $R$ Square) dari model regresi digunakan untuk mengetahui seberapa besar kemampuan variabel bebas (independen) dalam menerangkan variabel terikat (dependen). Dari tabel diatas diketahui bahwa nilai $\mathrm{R}^{2}$ sebesar 0,163 , hal ini berarti bahwa $16,3 \%$ menunjukkan bahwa harga berpengaruh terhadap keputusan pembelian. Sisanya sebesar $83.7 \%$ dipengaruhi oleh variabel lainnya yang tidak dimasukkan kedalam model regresi dalam penelitian ini.

Uji hipotesis dilakukan dan menghasilkan nilai signifikan 0,000 yang lebih kecil dari pada batas level signifikan yang telah ditentukan yakni 0,05 sehingga uji hipotesis ini menyatakan bahwa Harga (X) berpengaruh positif terhadap keputusan pembelian (Y). analisis sederhana dari uji hipotesis ini menghasilkan persamaan regresi $\mathrm{Y}=6,866+0,251 \mathrm{x}+\mathrm{e}$. Artinya konstanta memiliki nilai sebesar 6,866 mengidentifikasikan variable $\mathrm{Y}$ yaitu keputusan pembelian. Jika variable $\mathrm{X}$ yaitu Harga bernilai no (0), maka nilai keputusan pembelian adalah sebesar 6,866 dan nilai koefisien regresi harga sebesar 0,251 mengidentifikasikan bahwa setiap peningkatan harga akan mengakibatkan nilai keputusan pembelian sebesar 0,251 satuan.

Hal ini mengindikasikan bahwa harga berpengaruh positif terhadap keputusan pembelian di online shop tokopedia. Dengan demikian dapat disimpulkan bahwa harga memiliki pengaruh yang positif terhadap keputusan pembelian di online shop tokopedia.

Hasil dari analisi statistic hipotesis menunjukan hasil dari analisis statistic hipotesis menunjukan $\mathrm{R}^{2}$ sebesar 0,163 atau bearti bahwa $16,3 \%$ menunjukan bahwa harga dipengaruhi oleh keputusan pembelian di online shop tokopedia. Sisanya sebesar $83,7 \%$ dipengaruhi oleh variable lainnya yang tidak dimasukan ke dalam model regresi di penelitian ini.

Berdasarkan pengujian uji $\mathrm{t}$ menghasilkan nilat $\mathrm{t}$ dan sig untuk variabel independen yang akan digunakan dalam pengambilan keputusan dalam uji $\mathrm{T}$ ini. Uji $\mathrm{T}$ yang dilakukan dalam penelitian ini dengan melihat nilai signifikannya kemudian dibandingkan dengan tingkat signifikan sebesar 0,05. Jika sig lebih besar dari tingkat signifikan maka $\mathrm{H}_{0}$ akan diterima tapi jika nilai signifikan lebih kecil maka $\mathrm{H}_{0}$ ditolak. Dan hasil dari pengujian uji $\mathrm{T}$ ini adalah sig lebih besar dari 0,05 yang berarti nilai $\mathrm{H}_{0}$ diterima. 


\section{KESIMPULAN}

Berdasarkan hasil penelitian dan pembahasan tentang analisis pengaruh harga terhadap keputusan pembelian di online shop tokopedia, maka dapat disimpulkan bahwa harga berpengaruh positif signifikan terhadap keputusan pembelian di online shop toko pedia. Hal ini didukung dengan hasil analisis data yang telah dilakukan pengujian dimana hasil uji $\mathrm{T}$ hitungnya yang dilakukan dalam penelitian ini dengan melihat nilai signifikannya kemudian dibandingkan dengan tingkat signifikan sebesar 0,05 . Jika sig lebih besar dari tingkat signifikan maka $\mathrm{H}_{0}$ akan diterima tapi jika nilai signifikan lebih kecil maka $\mathrm{H}_{0}$ ditolak. Dari hasil nilai sig sebesar 0,000 yang berarti lebih kecil dibandingkan dengan tingkat signifikansi sebesar 0,05 yaitu $0,000<0,05$. Maka dapat disimpulkan bahwa $h_{0}$ ditolak dan $h_{a}$ diterima yang menunjukkan bahwa harga merupakan faktor yang mempengaruhi keputusan pembelian di toko online.

\section{UCAPAN TERIMA KASIH}

Syukur Alhamdulillah penulis ucapkan kepada Allah SWT, yang telah memberikan rahmat dan hidayah-Nya, sehingga akhirnya penulis dapat menyelesaikan Penelitian ini dengan judul "Analisis Pengaruh Harga Terhadap Keputusan Pembelian di Online Shop Tokopedia“.

Dalam menyusun skripsi ini banyak sekali pihak - pihak yang memberikan bantuan dan dukungan kepada penulis baik secara akademik maupun non akademik. Pada kesempatan ini panulis ingin menyampaikan ucapan terima kasih yang tulus kepada semua pihak yang telah memberikan dukungan, bimbingan, semangat, motivasi, dan doa.

Oleh karna itu dalam kesempatan ini penulis ingin mengucapkan terima kasih yang sebesar - besarnya kepada :

1. Bapak Febryandhie Ananda, SE, M.Si, selaku Ketua STIE KBP, dosen pembimbing akademik sekaligus dosen pembimbing dalam pembuatan skripsi ini yang telah memberikan pengarahan dan saran serta dorongan yang sangat berarti bagi penulis dalam penyelesaian skripsi ini.

2. Ibuk Lidya Marta, SE, MM, selaku wakil Ketua STIE KBP.

3. Ibuk Dewi Zulvia, SE, MM. selaku Ketua Prodi Akuntansi yang juga memberikan pengarahan dan saran bagi penulis.

\section{DAFTAR PUSTAKA}

Afsari, S. F. (2015). Analisis Faktor - Faktor Yang Mempengaruhi Kecenderungan Kecurangan (Fraud) di Sektor Pemerintahan Berdasarkan Teori Fraud Triangle, 115.

Akbar, A. (2012). Analisis Pengaruh Citra Merek, Harga, dan Kualitas Produk 
Terhadap Keputusan Pembelian Notebook Toshiba, 1-21.

Ananda, F., Putra, R. D., \& Hendrastyo, V. S. (2017). Kesuksesan Implementasi System Application Product (SAP) studi kasus di PT. Semen Padang. Jurnal Pundi, 1(1), 1-10. https://doi.org/10.31575/jp.v1i1.4

Ananda, F., \& Zulvia, D. (2018). Indikasi machiavellianism dalam pembuatan keputusan etis auditor pemula. Benefita, 3(September), 357-369. https://doi.org/10.22216/jbe.v3i3.3660

Arwiedya, \& Ridzky, M. (2011). Analisis Pengaruh Harga, Jenis Media Promosi, Resiko Kerja Terhadap Keputusan Pembelian Via Online( Studi Kasus Pada Konsumen Toko Fashion Online yang bertindak.

Ghozali, I. (2009). Aplikasi Analisis Multivariate Dengan Program SPSS (Keempat). Diponegoro: Universitas Diponegoro.

Kloter, \& Armstrong. (2001). Pengertian Harga Menurut Para Ahli.

Kotler \& Philip. (2009). Manajemen Pemasaran. Jakarta: Erlangga.

Kurniasari, N. D. (2013). Analisis Pengaruh Harga, Kualitas Produk, dan Kualitas Pelayanan Terhadap Keputusan Pembelian (Studi Kasus Pada Konsumen Waroeng Steak \& Shake Cabang Jl. Sriwijaya 11 Semarang), 2.

Nurjanah. (2013). Analisis pengaruh lokasi, persepsi harga dan promosi terhadap keputusan pembelian konsumen.

Piyatno, D. (2014). SPSS 22 Pengolah Data Terparaktis. (Arie Prabawati, Ed.). Yogyakarta: Andi Yogyakarta.

Sarwono, J. (2006). Analisis Data Penelitian Menggunakan SPSS. Yogyakarta: CV Andi Offset.

Sugiyono. (2016). Metode Penelitian Kuantitatif, Kualitatif dan R\&D. Bandung: Alfabeta.

Tokopedia. (2018). Tentang Tokopedia. 